\title{
IAMJ
}

INTERNATIONAL

AYURVEDIC

MEDICAL JOURNAL

Review Article

ISSN: 2320-5091

Impact Factor: 6.719

\section{REVIEW ON MEDOVAHASROTAS AND ITS MOOLSTHANA WITH REFERENCE TO OBESITY INDUCED HYPERTENSION}

$\underline{\text { Jinu K Mathew }}^{1}$, Jaishree H Mhaisekar ${ }^{2}$

${ }^{1}$ PG Scholar, ${ }^{2}$ Associate Professor

Dept. of Rachana Sharir, Government Ayurveda College, Nagpur, Maharashtra, India

Corresponding Author: jinukidangayil@gmail.com

\section{https://doi.org/10.46607/iamj2409042021}

(Published Online: April 2021)

Open Access

(C) International Ayurvedic Medical Journal, India 2021

Article Received: 26/03/2021 - Peer Reviewed: 30/03/2021 - Accepted for Publication: 31/03/2021

Check for updates

\section{ABSTRACT}

Excess weight gain, especially when associated with increased visceral adiposity, is a major cause of hypertension accounting $65-75 \%$ of total cases of hypertension. Increased renal tubular sodium reabsorption by the impairment in renal pressure natriuresis plays an important role in initiating obesity induced hypertension. The present study conceptually tries to substantiate the relation between moolasthana described for medovahasrotas with reference to the pathology of obesity induced hypertension. The moola explained for medovahasrotas are Kati, Vrikka, Vapavahana and Mamsa (Kidney, Suprarenal gland, Lumbosacral region, Superficial fat) which are the general regions of deposition of visceral fat or meda. The increased meda will hamper the renal pressure natriuresis in mainly three ways:

1)Physical compression of the kidneys by fat in and around kidney.

2)Increased activation of RAAS.

3)Increased SNS activity.

Thus, medovaha srotodushti further enhances medodhatudushti (Obesity or Sthoulyata) itself, which in turn destroys the srotomoola. Hence, evidence of inherent relation among medovaha srotas and its respective srotomoola is established.

Keywords: Medovahasrotas, Srotomoola, obesity induced hypertension 


\section{INTRODUCTION}

Srotas are defined as the channels or pores which continuously carry out the function of secretion, transportation, and excretion in the body ${ }^{1}$. They help in the transportation of dosha and dhatu in the body during equilibrium state. The concept of srotas has been described by Charak, Susruta, Vagbhat etc even though there is slight difference in their numbers. Dhatu in the body are present in two forms.1) Poshya dhatu (That getting nourishment) 2) Poshak dhatu (Nourishing). Among these poshak dhatu are present in Srotas and poshya dhatu being present in kala, receives nourishment from poshak dhatu. Each Srotas carry only their respective poshak dhatu and thereby called upon by the name of dhatu itself. Hence, the srotas that transports the medodhatu throughout the body are called as Medovaha Srotas. Each srotas consist of two parts or ends, one from which the srotas are getting originated (Moola), another which the nutritive material is being transported to respective sites. It has been clearly described in samhitas about srotomoola, srotodushti hetu, srotodushti lakshana of each srotas. This study tries to elicit the relation between medovaha srotas and its moolasthana with due consideration with structural involvement and pathophysiology of Obesity Induced Hypertension which is a major problem faced among the developed and developing countries.

\section{Aim and Objectives}

- To study the concept of medovaha srotas.

- To evaluate the relation between medovaha srotas and its srotomoola by correlating the medovaha srotodushti lakshana with pathophysiology of obesity induced hypertension.

\section{Materials and Method}

This is a conceptual study. Detailed literature of medovaha srotas were collected from classical ayurvedic texts and modern pathophysiology of obesity induced hypertension from journals and modern texts.

\section{Literature Review}

The term srotas is derived from the root word 'susravana' means to exude, to ooze, to filter. Medas is derived from 'Jhimida snehana', means the substance which has snigdatva property. The word moola means root, it may be root of origin, root of manifestation, root of nutrition etc.

\section{Medovaha Srotomoola}

$\begin{array}{ll}\text { Vrikka, Vapavahana } & \text { - Charaka } \\ \text { Vrikka, Kati } & \text { - Susruta } \\ \text { Vrikka, Mamsa } & \text { - Vagbhata }\end{array}$

Vrikka - Koshtanga formed by the sara of rakta and medodhatu. There are two vrikka. The term vrikka may include the kidney along with the suprarenal glands.

Vapavahana -It is also a koshtanga. Chakrapani interpreted as Tailavartika. Dr. Ghanekar commented it as omentum, where maximum meda is stored.

Kati -It denotes to the flanks or lumbosacral region where fat accumulates.

Mamsa -It is not yet interpreted satisfactorily, yet superficial fat over muscle can be considered.

\section{Medovaha Srotodushti Hetu}

Avyayama, divaswapna, atisnigda-ahaar sevana and atisevana of varuni madhya are described as hetu for medovaha sroto dushti by Charaka in srotovimana adhyay $^{3}$ which means lack of exercise, daytime sleep, eating too much oily food, and excess intake of alcohol especially wines vitiate the medovaha srotas.

\section{Medovaha Srotodushti Lakshana}

Srotodushti lakshana is described by Charak where as Susruta being salyapradhana described srotoviddha lakshana. Anyhow Dalhana in the commentary clarifies this difference. According to Charaka dushtilakshana includes premonitory symptoms explained for prameha, the eight doshas explained for atisthoola i.e. decrease of life span, enthusiasm, infertility, bad odour of body, excessive sweating, excessive appetite and thirst etc $^{4}$. Susruta describes symptoms of injury to medovaha strotomoola as excessive sweating, oily appearance of body, dryness of palate, obesity, oedema, and thirst. ${ }^{5}$

The term medoroga was first used by Acharya Madhava. It is used as a broad term which include obesity and related metabolic syndrome. Adhamalla further tried to distinguish between two types of medoroga 1) Obesity with its clinical features (sthoulyata) 2) Lipid disorders where meda acts as an 
etiological factor in the genesis of other secondary diseases.

\section{Obesity Induced Hypertension}

Excess weight gain, especially when associated with increased visceral adiposity is a major cause of hypertension, accounting for $65-75 \%$ of the risk of human primary hypertension. Studies in diverse population of the world have shown that there exist a linear relationship between BMI and systolic and diastolic blood pressure ${ }^{6,7}$. Clinical studies indicate that maintenance of a $\mathrm{BMI}<25 \mathrm{~kg} / \mathrm{m}^{2}$ is effective in primary prevention of hypertension ${ }^{8,9}$.

The impact of obesity on BP mainly depends on a) How long the person has been overweight $b$ ) The distribution of fat on the body. It worsens the condition if excess adiposity is maintained over several years. Also, apart from mere raised BMI of subcutaneous fat, it is the visceral or retroperitoneal fat which makes vulnerable to hypertension ${ }^{10}$.

\section{Impaired Renal Pressure Natriuresis}

Impaired renal pressure natriuresis is the basic cause of hypertension in obese subjects. Mainly, three major factors are responsible for the pathology.

1) Physical compression over the kidneys due to increased visceral, retroperitoneal and renal sinus fat.

2) RAAS (Renin-Angiotensin-Aldosterone System) activation

3) SNS (Sympathetic Nervous System) activation, especially renal sympathetic nerve activity.

In addition to this, CKD (Chronic Kidney Disease) over a much longer time amplify the effects in obese persons.

\section{Increasing Blood Pressure by Physical Compression} Increased visceral and retroperitoneal fat may increase blood pressure by physically compressing the kidneys. In patients with visceral obesity, intraabdominal pressure rises in proportion to sagittal abdominal diameter reaching high levels as high as 35-40 $\mathrm{mmHg}^{11}$. These high pressures compress the renal veins, lymph vessels, ureters and renal parenchyma. Also, retroperitoneal fat often encapsulates the kidney, attach tightly to the renal capsule and invades the renal sinuses, causing additional effects on intrarenal pressure $^{12}$.In addition to compressing the kidneys, retroperitoneal and renal sinus fat may cause inflammation and expansion of renal medullary extracellular matrix that could further impair renal function. The compression on kidney by visceral fat increases the interstitial fluid pressure which will compress the thin loops of Henle and vasa recta, reducing renal tubular flow and medullary blood flow, thereby increasing sodium reabsorption in the loop of Henle. Increased sodium reabsorption will contribute to renal vasodilation, glomerular hyperfiltration and renin secretion eventually resulting in hypertension ${ }^{13}$.

\section{RAAS (Renin Angiotensin Aldosterone System)}

Obese subjects, especially those with visceral obesity, often have mild to moderate increase in plasma renin activity, angiotensinogen, ACE activity, Angiotensin 2, and aldosterone ${ }^{14}$. RAAS activation occurs despite $\mathrm{NaCl}$ retention, Volume expansion and Hypertension which typically suppress renin secretion and Angiotensin 2 formation. Abnormal activation of RAAS system will result in $\mathrm{NaCl}$ reabsorption and there is increase of ECF and eventually elevation of blood pressure. Abnormal activation of RAAS may contribute to glomerular injury and loss associated with obesity not only by increasing blood pressure but also through intrarenal effects. Thus, constriction of efferent arterioles by Angiotensin 2 modulates the rise in glomerular hydrostatic pressure caused by arterial hypertension.

\section{SNS activation}

Obesity generally decreases parasympathetic tone and increases sympathetic activity. These changes in autonomic activity are associated with increased heart rate, reduced baroreflex sensitivity as well as hypertension ${ }^{15,16}$. Although cardiac SNS activity may not be elevated, RSNA (Renal Sympathetic Nerve Activity) and MSNA (Muscle Sympathetic Nerve Activity) are generally increased in obese compared to lean subjects ${ }^{17,18}$. Increased RSNA stimulates renin secretion and renal sodium reabsorption which in turn contribute in developing obesity hypertension. Visceral obesity elicits greater SNS activation than does subcutaneous obesity. Several mediators of SNS activation in obesity have been suggested including:

1) Impaired baroreceptor reflexes 
2) Hyperinsulinemia 3) Angiotensin II

4) Cytokines released from adipocytes such as leptin, tumor necrosis factor and interleukin-6

5) CNS propriomelanocortin pathway.

\section{DISCUSSIONS}

It is well clear that direct correlation of medovahasrotomoola with probable modern anatomical structures like kidney, lumbosacral region, superficial fascia is possible since because of the variable amount of deposition of fat (meda) in these areas. But the greatness of the work of ancient Acharyas are so fascinating that, even the pathophysiology also can be well explained by relating these structures. The increase in blood pressure in the body are normally achieved by combined effects of RAAS mechanism and SNS activity. The activation of RAAS and SNS will take place when there occurs a fall in blood pressure. This normal physiology will get hampered in obese people ,especially in those having visceral adiposity. In impaired renal pressure natriuresis, the above normal physiological process will deviate from normalcy. The principal cause of this impairment is the deposition of visceral fat i.e. meda over the body. Excess deposition of meda is nothing but the medodhatu dushti which eventually hamper the respective srotomoola itself. Hence, samprapti can be summarised as

\section{Medovahasrotodushtihetu $\Rightarrow$ Medovahasrotodushti}

$\Rightarrow$ Medodhatudushti $\Rightarrow$ Medovahasrotomoola dushti When impairment in renal pressure natriuresis persists over a long period of time, will leads to Chronic Kidney Disease in which pedal oedema is a classic presentation. Susruta includes Sthulasophata as a lakshana of medovaha srotomoola vidha/dushti. Thus, it can be concluded that there is inherent relation of medovaha srotas with its moolasthana, and any dearrangement of its normal function eventually lead to the destruction of srotomoola. So, the line of treatment of obesity induced hypertension should be made by considering the srotomoola dushti and by avoiding medovaha srotodushti hetu apart from antihypertensive drugs.

\section{CONCLUSION}

There exists an inherent relation between medovahasrotas and its srotomoola. Any dearrangements in any of the two, will hamper the other and resulting in malfunctioning of the system.

\section{REFERENCES}

1. Shastri K, Chaturvedi G, Charak Samhita Vidyotini tika, 1st edition. Varanasi: Chaukhambha Bharati Academy; 2008. Vol. I, Page no.709.

2. Shastri Ambikadutta, Sushruta Samhita Ayurveda Tattva Sandipika, 1st edition. Varanasi: Chaukhambha Sanskrit Sansthan; 2014. Vol. i, Page no.97.

3. Shastri K, Chaturvedi G, Charak Samhita Vidyotini tika, 1st edition. Varanasi: Chaukhambha Bharati Academy; 2008. Vol. i, Page no.713.

4. Kaviraja Gupta Atrideva, Astanga Hrdayam Vidyotini tika, 1st edition. Varanasi: Chaukhambha Prakashan; 2016. Vol. i, Page no.115.

5. Shastri Ambikadutta, Sushruta Samhita Ayurveda Tattva Sandipika, 1st edition. Varanasi: Chaukhambha Sanskrit Sansthan; 2014. Vol. i, Page no.97.

6. Hall JE. The kidney, hypertension, and obesity. Hypertension. 2003; 41:625-633. [PubMed: 12623970]

7. Jones DW, Kim JS, Andrew ME, Kim SJ, Hong YP. Body mass index and blood pressure in Korean men and women: the Korean National Blood Pressure Survey. J Hypertens. 1994; 12:1433-1437. [PubMed: 7706705]

8. Jones DW, Miller ME, Wofford MR, Anderson DC Jr, Cameron ME, Willoughby DL, Adair CT, King NS. The effect of weight loss intervention on antihypertensive medication requirements in the hypertension Optimal Treatment (HOT) study. Am J Hypertens. 1999; 12:1175-1180. [PubMed: 10619579]

9. Stevens VJ, Obarzanek E, Cook NR, et al. Long-term weight loss and changes in blood pressure: results of the Trials of Hypertension Prevention, phase II. Ann Intern Med. 2001; 134:1-11. [PubMed: 11187414]

10. Tchernof A, Despres JP. Pathophysiology of human visceral obesity: an update. Physiol Rev. 2013; 93:359404. [PubMed: 23303913]

11. Sugerman H, Windsor A, Bessos M, Wolfe L. Intraabdominal pressure, sagittal abdominal diameter and obesity comorbidity. J Intern Med. 1997; 241:71-79. [PubMed: 9042096]

12. Hall JE, Crook ED, Jones DW, Wofford MR, Dubbert PM. Mechanisms of obesity-associated cardiovascular 
and renal disease. Am J Med Sci. 2002; 324:127-137. [PubMed: 12240710]

13. Hall M E, do Carmo JM, da Silva AA, Juncos LA, Wang Z, Hall JE. Obesity, hypertension, and chronic kidney disease. Int J Nephrol Renovasc Dis. 2014; 7:75-88. [PubMed: 24600241]

14. Engeli S, Sharma AM. The renin-angiotensin system and natriuretic peptides in obesity-associated hypertension. J Mol Med (Berl). 2001; 79:21-29. [PubMed: 11327100]

15. 15.Hall JE, da Silva AA, do Carmo JM, Dubinion J, Hamza S, Munusamy S, Smith G, Stec DE. Obesityinduced hypertension: role of sympathetic nervous system, leptin, and melanocortins. J Biol Chem. 2010; 285:17271-17276. [PubMed: 20348094]

16. 16.Van Vliet BN, Hall JE, Mizelle HL, Montani JP, Smith MJ Jr. Reduced parasympathetic control of heart rate in obese dogs. Am J Physiol. 1995; 269:H629H637. [PubMed: 7653627]

17. 17.Davy KP, Hall JE. Obesity and hypertension: two epidemics or one? Am J Physiol Regul Integr Comp Physiol. 2004; 286: R803-R813. [PubMed: 15068965] 66.

18. 18.Rumantir MS, Vaz M, Jennings GL, Collier G, Kaye DM, Seals DR, Wiesner GH, Brunner-La Rocca HP, Esler MD. Neural mechanisms in human obesity-related hypertension. J Hypertens. 1999; 17:1125-1133. [PubMed: 10466468]

19. da Silva A A, do Carmo JM, Wang Z, Hall JE. The brain melanocortin system, sympathetic control, and obesity hypertension. Physiology (Bethesda). 2014; 29:196202. [PubMed: 24789984]

20. do Carmo JM, da Silva AA, Dubinion J, Sessums PO, Ebaady SH, Wang Z, Hall JE. Control of metabolic and cardiovascular function by the leptin-brain melanocortin pathway. IUBMB Life. 2013; 65:692-698. [PubMed: 23847053]

21. da Silva A A, do Carmo JM, Hall JE. Role of leptin and central nervous system melanocortins in obesity hypertension. Curr Opin Nephrol Hypertens. 2013; 22:135-140. [PubMed: 23299052]

\section{Source of Support: Nil Conflict of Interest: None Declared}

How to cite this URL: Jinu $\mathrm{K}$ Mathew \& Jaishree $\mathrm{H}$ Mhaisekar:Review on Medovahasrotas and it's Moolsthana with Reference to Obesity Induced Hypertension. International Ayurvedic Medical Journal \{online\} 2021 \{cited April, 2021\} Available from: http://www.iamj.in/posts/images/upload/833_837.pdf 